\title{
Octopamine- and Cyclic AMP-Stimulated Phosphorylation of a Protein in Limulus Ventral and Lateral Eyes
}

\author{
Samuel C. Edwards and Barbara-Anne Battelle \\ C. V. Whitney Laboratory of the University of Florida, St. Augustine, Florida 32086, and National Institutes of Health, \\ National Eye Institute, Bethesda, Maryland 20205.
}

The biogenic amine octopamine (OCT) fulfills most of the criteria as a neurotransmitter of efferent fibers that project to lateral and ventral eyes of the horseshoe crab, Limulus polyphemus. OCT is synthesized by and released from the efferent fibers, and OCT mimics many of the effects of endogenous efferent activity. OCT stimulates an increase in intracellular adenosine $3^{\prime}, 5^{\prime}$-monophosphate (CAMP) in both ventral and lateral eyes, and many of the physiological effects of OCT in these eyes appear to be mediated via CAMPdependent mechanisms. Here we show that OCT, acting apparently through an OCT-specific receptor, stimulates the increased phosphorylation of a protein with an apparent molecular weight of $122 \mathrm{kDa}$ in both ventral and lateral eyes. This protein is also phosphorylated in response to 8-bromo CAMP and forskolin, suggesting that its phosphorylation involves activation of a cAMP-dependent protein kinase. We present evidence that the $122 \mathrm{kDa}$ protein may be widely distributed in the Limulus visual system but that its phosphorylation in intact tissue in response to OCT, or agents acting through CAMP, may be restricted to portions containing photoreceptor cell bodies. The $122 \mathrm{kDa}$ protein is quantitatively a major cellular protein in the photoreceptor cell body enriched portions of the ventral eye, its isoelectric polnt is between pH 6.2 and 6.4, and it is associated with both cell membranes and the cytoplasm. The function of this protein is not yet known. It may be important in mediating one or more of the effects of octopamine on Limulus vision.

Almost universally, the retinas of animals are innervated by neurons that have their cell bodies located in the brain. This centrifugal or efferent input is presumed to be regulatory, but the details of its functions are mostly unknown. The best understood of these retinal efferent systems is the one projecting to the eyes of the horseshoe crab, Limulus polyphemus. Efferent fibers innervate all of the eyes of Limulus - lateral, ventral, and median - and they are driven by a circadian clock located in the CNS. The efferent neurons become active at night and are silent

Received Oct. 14, 1986; revised Jan. 29, 1987; accepted Feb. 20, 1987.

This work was supported in part by an NEI postdoctoral fellowship (F32 EY0572403) to S.C.E., the Whitehall Foundation, and the C. V. Whitney Laboratory of the University of Florida. We wish to thank Dr. Michael Goy for his advice on limited proteolytic digestion and acid hydrolysis of the protein and for critically reading the manuscript, Dr. Paul Russell and Mr. Paul Begovac for their advice on 2-dimensional gel electrophoresis, Dr. Michael Greenberg for his comments on the manuscript, Ms. Lynn Milstead and Mr. Jim Netherton for preparing the figures, and Ms. Heidi Maresch for her expert technical help.

Correspondence should be addressed to Samuel C. Edwards, Ph.D., C. V. Whitney Laboratory, University of Florida, Route 1, Box 121, St. Augustine, FL 32086. Copyright (C) 1987 Society for Neuroscience $0270-6474 / 87 / 092811-10 \$ 02.00 / 0$ during the day (Barlow et al., 1977). When the fibers are active, the anatomy, biochemistry, and electrophysiology of cells in the lateral eye change, leading to an increase in the sensitivity of the eye to light (see recent reviews by Battelle, 1984; Barlow et al., 1985). Furthermore, efferent input to the lateral eye at night is required for the normal shedding of photosensitive membrane the next morning (Chamberlain and Barlow, 1979).

There is substantial evidence that the biogenic amine octopamine (OCT) is a neurotransmitter synthesized and relcased from the efferent fibers in Limulus eyes (Battelle et al., 1982; Evans et al., 1983, Battelle and Evans, 1984). Application of OCT to the lateral eye in situ (Kass and Barlow, 1984) or in an isolated preparation (Pelletier et al., 1984) mimics many of the electrophysiological effects of endogenous efferent innervation. Moreover, in the in situ preparation, clozapine, an OCT receptor blocker (Dougan and Wade, 1978; Evans 1981), blocks both the physiological effects of exogenously added OCT and those generated by endogenous efferent activity (Kass and Barlow, 1984). Thus, OCT is very likely the neurotransmitter responsible for many of the effects of efferent innervation observed in the lateral eye. Application of OCT to isolated photoreceptor cells of the Limulus ventral eye increases their rate of dark adaptation following a bright illumination (O'Day and Lisman, 1985) and increases the sensitivity of light-adapted photoreceptor cells (Stieve and Andre, 1984).

OCT increases the level of intracellular adenosine $3^{\prime}, 5^{\prime}$-monophosphate (cAMP) in both the ventral (Kaupp et al., 1982) and lateral eye (B.-A. Battelle, unpublished observations). Many of the effects of OCT in the lateral (Kass et al., 1983; Pelletier et al., 1984) and ventral eye (O'Day and Lisman, 1985) can be mimicked by cAMP analogs or forskolin, a nonspecific adenylate cyclasc stimulator (Scamon ct al., 1981). Thus, many effects of OCT seem to be mediated by the second-messenger cAMP.

An increase in intracellular cAMP leads to the phosphorylation of substrate proteins by activating cAMP-dependent protein kinase in many different systems (Nestler and Greengard, 1984). These phosphorylated proteins are thought to be the protein intermediates through which specific physiological processes are carried out. OCT stimulates the phosphorylation of specific proteins in lobster muscle (Goy et al., 1984), in nervous tissue of the marine gastropod mollusc Aplysia californica (Levitan and Barondes, 1974), and in Limulus skeletal muscle (Edwards and Pierce, 1984). Thus OCT, released from retinal efferent fibers onto cells in the Limulus eye, may produce some of its effects on Limulus vision by stimulating the cAMP-dependent phosphorylation of specific proteins.

In the present study we demonstrate that OCT, acting ap- 
parently through specific receptors, stimulates the phosphorylation of a protein with an apparent molecular weight of 122 $\mathrm{kDa}$ in a fraction of the Limulus ventral eye rich in photoreceptor cell bodies (P-fraction) and in the lateral eye. We show that this protein can be phosphorylated via a cAMP-dependent mechanism. The $122 \mathrm{kDa}$ OCT-stimulated phosphoprotein is a major cellular component of the ventral eye P-fractions, and it occurs both in the cytoplasm and in association with membranes.

\section{Materials and Methods}

Animals. Some adult, intermoult Limulus polyphemus were supplied by Gulf Specimens (Panacea, FL) and were maintained under constant light conditions in continuously aerated artificial seawater $\left(12^{\circ} \mathrm{C}\right)$. Others were obtained from the Whitney I aboratory (St. Augustine, FI) or from the Marine Biological Laboratory (Woods Hole, MA) and were maintained under ambient light conditions in running, natural seawater. Animals from the different sources gave qualitatively similar results.

Phosphorylation in intact cells. The ventral eyes, proximal segments of the lateral optic nerve (LON), and lateral eyes were removed from animals during the afternoon and placed into MOPS buffered Limulus saline (Warren and Pierce, 1982) containing $5 \mathrm{~mm}$ glucose. The ventral optic nerves were dissected free of surrounding blood vessels and divided into photoreceptor cell body-rich fractions ( $P$-fractions) and axonal-rich fractions (A-fractions), which were virtually devoid of photoreceptor cell bodies (Battelle, 1980). The P-fractions were divided further so that 4 samples containing approximately the same number of photoreceptor cell bodies were obtained from each animal. Generally, photoreceptor cell bodies from the end organ and those dispersed more proximally along the ventral optic nerve were in different samples. Preliminary experiments showed that cells from these two different locations were experimentally indistinguishable. $U p$ to four A-fractions were also cut from similar regions of the ventral optic nerve. Each sample contained approximately the same amount of tissue as the corresponding P-fractions. P- and A-fractions of the ventral eyes, segments of the LON, and small slices from the central region of the lateral eye with the cornea attached were incubated overnight in saline in the dark at $4^{\circ} \mathrm{C}$.

The next day the samples were brought to room temperature in the light and preincubated with ${ }^{32} \mathrm{P}$ orthophosphate $(\mathrm{ICN}, 2.3 \mathrm{mC} / \mathrm{ml}, 90$ nM phosphate final concentration) for $1.5 \mathrm{hr}$. They were then incubated with different concentrations of D,L-OCT (Sigma) or other test substances in the presence of ${ }^{32} \mathrm{P}$ orthophosphate for the times indicated in the legends to the figures.

To prepare the tissues for analysis by SDS-PAGE, the incubations were terminated by addition of an equal volume of double-strength Laemmli (1970) SDS electrophoresis buffer and by sonication with a bath sonicator (Heat Systems). Preliminary tests showed that sonication produced the same results as placing the samples in a boiling water bath for $5 \mathrm{~min}$.

For analysis by 2-dimensional separation using isoelectric focusing (IEF) followed by SDS-PAGE, experiments were terminated by the addition of SDS and 2-mercaptoethanol such that their final concentrations were 2 and $5 \%$, respectively. The samples were stored at $-70^{\circ} \mathrm{C}$ until analyzed.

$S D S-P A G E$ and autoradiography. Proteins were separated by SDSPAGE (Laemmli, 1970) using 7.5\% acrylamide in the separating gel. Proteins of the ventral eye were visualized with silver stain (BioRad) and those from LON and lateral eye with Coomassie blue G-250. Incorporation of ${ }^{32} \mathbf{P}$-phosphate was visualized in dried gels using Kodak XAR film. The molecular weights of the phosphoproteins were calculated from the migration of protein standards (Weber and Osborn, 1969).

Relative incorporation of ${ }^{32} \mathrm{P}$ into specific protein bands in each $P$-fraction sample was quantified from densitometric scans of the autoradiographs (Transidyne model 2500). The areas of the absorbance peaks were determined gravimetrically. The basal level of protein phosphorylation differed in individual samples of intact tissues, perhaps reflecting variations in ${ }^{32} \mathbf{P}$ uptake. Therefore, reference proteins were identified that did not respond to the experimental treatments with a change in phosphorylation, and all results are expressed as the ratio of the absorbance associated with the protein of interest to that of a reference protein. In the experiments with the intact P-fractions, a $95 \mathrm{kDa}$ protein band was chosen to be the reference protein. There was no significant change $(p<0.05)$ in the amount of ${ }^{32} \mathrm{PO}_{4}$ associated with this band in response to any of the experimental treatments when compared with the total amount of ${ }^{32} \mathrm{PO}_{4}$ associated with the other protein bands in the P-fraction.

In all experiments with intact tissues, the untreated control tissues and experimental tissues were taken from the same animal. The results of each experiment were statistically evaluated using an analysis of variance in a randomized complete block design. Thereafter, the effects of individual treatments were tested using Duncan's new multiple-range test (Steel and Torrie, 1980). A probability of $p<0.05$ was considered significant.

Subcellular localization of the $122 \mathrm{kD}$ a protein. Intact $\mathrm{P}$-fractions from 2 animals were pooled, randomly divided into 2 samples, and then maintained overnight in the dark in saline $\left(4^{\circ} \mathrm{C}\right)$. Both samples were preincubated with ${ }^{32} \mathrm{P}$ orthophosphate as described above, then one was challenged with $2 \mu \mathrm{M}$ OCT for $5 \mathrm{~min}$. The samples were then homogenized at $0^{\circ} \mathrm{C}$ in a hypoosmotic $20 \mathrm{~mm}$ Tris HCl-buffered solution $(\mathrm{pH}$ 7.5) containing $0.25 \mathrm{M}$ sucrose, $0.1 \mathrm{~mm}$ dithiothreitol, $5 \mathrm{mM} \mathrm{Na}_{2} \mathrm{HPO}_{4}$, $1 \mathrm{mM} \mathrm{Na}{ }_{2}$ EDTA, $25 \mathrm{mM} \mathrm{NaF}$, and $0.1 \mathrm{~mm}$ phenylmethylsulfonyl fluoride (PMSF) using a Teflon-glass homogenizer. Each homogenate was centrifuged at $10,000 \times g$ for $30 \mathrm{~min}\left(4^{\circ} \mathrm{C}\right)$, and the resulting supernatant was centrifuged at $130,000 \times g$ for $60 \mathrm{~min}\left(4^{\circ} \mathrm{C}\right)$. A previous study of Limulus skeletal muscle (Edwards, 1984) showed that the above procedure separated characteristic membrane marker enzymes from soluble cell components. The pelleted materials resulting from the 2 centrifugation steps were resuspended by vortexing in homogenizing medium. Each sample was then analyzed by SDS-PAGE and autoradiography as described above.

Proteolytic digestion of the $122 \mathrm{kDa}$ protein. The $122 \mathrm{kDa}$ phosphoprotein, phosphorylated by treatment of intact P-fractions with OCT, forskolin (Calhiochem), or 8-bromo cAMP (Sigma) as described above, was subjected to limited proteolytic digestion with Staphylococcus aureus V8 protease (Sigma) or chymotrypsin (TPCK-treated; Sigma) using the method of Cleveland et al. (1977) as modified by Goy et al. (1984). The resulting phosphopeptides were detected by autoradiography employing intensifying screens (DuPont Cronex Lightning Plus).

Phosphoamino acid determination. The amino acids in the $122 \mathrm{kDa}$ phosphoprotein, which were labeled with ${ }^{32} \mathbf{P}$ in response to treatment of the ventral eye P-fractions with $2 \mu \mathrm{M}$ OCT, were identified using the procedures described by Cooper et al. (1983) and Benovic et al. (1985). Samples, together with phosphoserine, phosphothreonine, and phosphotyrosine standards (Sigma), were subjected to high-voltage paper electrophoresis at $\mathrm{pH} 1.9$ (Hildebrand et al., 1971). The migration of the standards was determined using ninhydrin. The association of ${ }^{32} \mathrm{P}$ with the phosphoamino acids was determined by autoradiography and liquid scintillation spectroscopy.

Phosphorylation in tissue homogenates. Cyclic AMP-stimulated phosphorylation in tissue homogenates was performed as described by Novak-Hofer et al. (1985). The homogenates were preincubated for $5 \mathrm{~min}$ at $30^{\circ} \mathrm{C}$, for 1 additional min with $30 \mu \mathrm{M}$ ATP containing $20 \mu \mathrm{Ci} \gamma^{-32} \mathrm{P}$ ATP (New England Nuclear, $0.35 \mathrm{nmol} / \mathrm{mCi}$ ), and then incubated for various times with $10 \mu \mathrm{M} 8$-bromo cAMP or control medium. For SDSPAGE analysis, the reaction was stopped by the addition of doublestrength Laemmli (1970) sample buffer and sonication. Samples were then stored at $4^{\circ} \mathrm{C}$ until analyzed. For 2-dimensional analysis, a solution of SDS and 2-mercaptoethanol was added to each sample, bringing their concentrations to 0.5 and $5 \%$, respectively. The samples were then stored at $-70^{\circ} \mathrm{C}$. The protein concentration of each homogenate was determined by a modified Lowry procedure (Peterson, 1977) using BSA as the standard.

$I E F$ and nonequilibrium $p H$ gradient 2-dimensional gel electrophoresis. IEF 2-dimensional gel electrophoresis (IEF-2D) was performed using the procedure described by O'Farrell (1975). Nonequilibrium $\mathrm{pH}$ gradient 2-dimensional gel electrophoresis (NEPHGE-2D) followed the procedure described by O'Farrell et al. (1977). In each case, the second dimension was run and processed as described above for SDS-PAGE and autoradiography, except that intensifying screens were used for detection of the phosphorylated proteins.

\section{Results}

Comparison of proteins and phosphoproteins in ventral eye $P$ - and A-fractions, lateral eye, and LON

The preparations analyzed differ in their cellular composition. The ventral eye $\mathrm{P}$-fraction is enriched in photoreceptor cell 
A

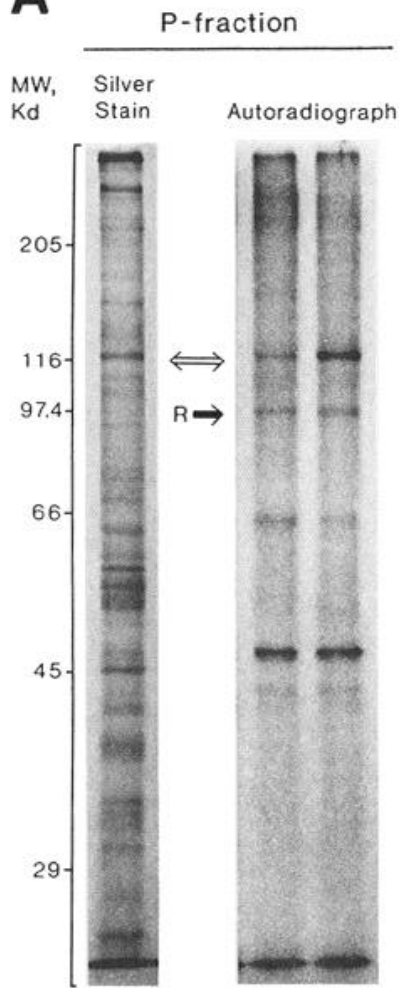

CON OCT

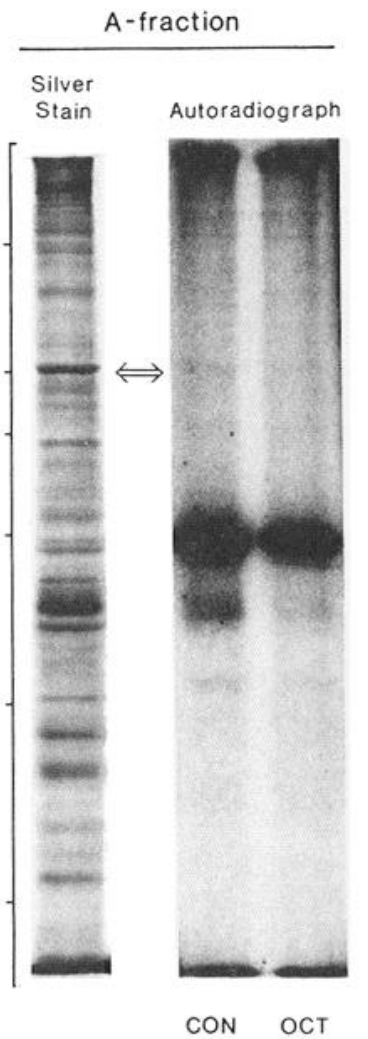

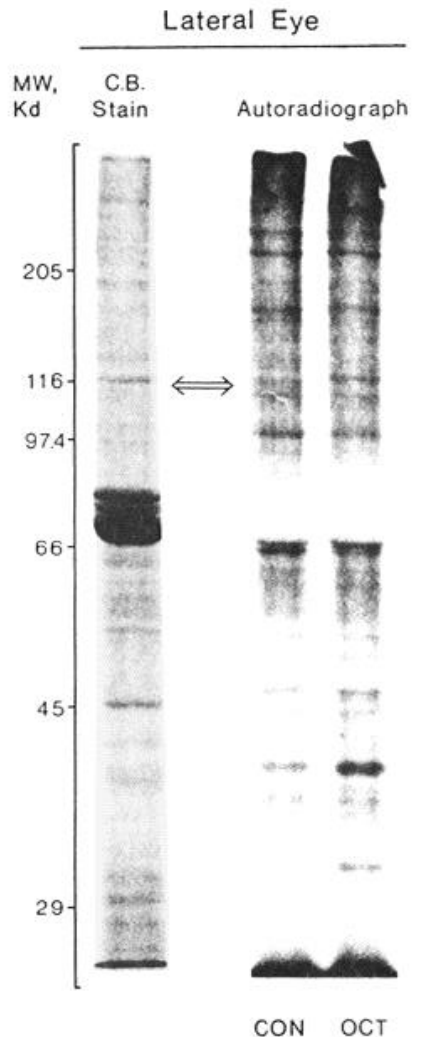

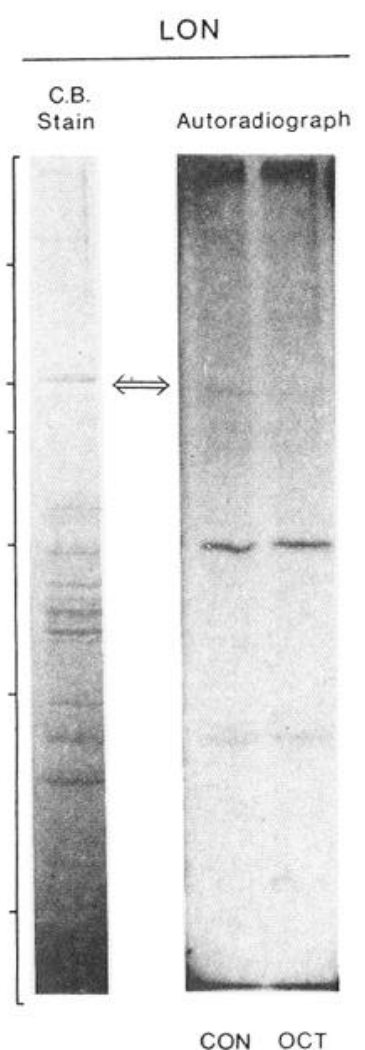

B

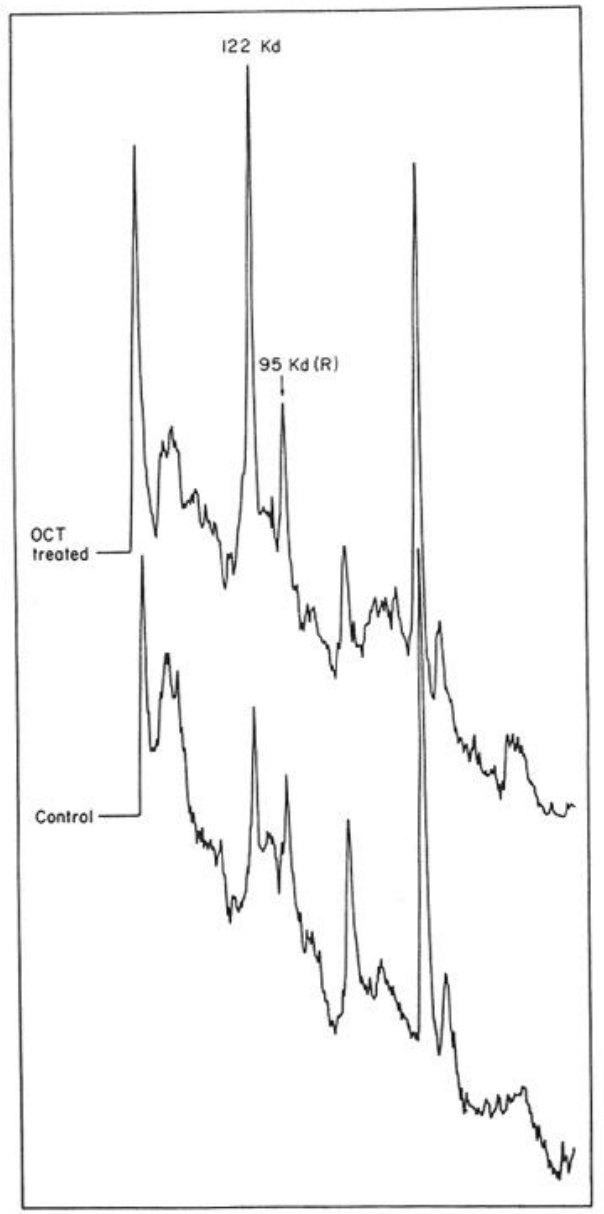

Figure 1. Octopamine stimulates the phosphorylation of a $122 \mathrm{kDa}$ protein band in Limulus ventral photoreceptors and lateral -yes but not on the optic nerves. Intact $\mathrm{P}$ - and $\mathrm{A}$-fractions of the ventral eye, as well as sections from the lateral eye and lateral optic nerve ( $L O N)$ were incubated for $1.5 \mathrm{hr}$ in saline containing ${ }^{32} \mathrm{P}$-orthophosphate $(2.3 \mathrm{mCi} /$ $\mathrm{ml}$ ) and then for an additional $5 \mathrm{~min}$ in the absence $(C O N)$ or presence of 2 $\mu \mathrm{M}$ OCT. A, Staining (silver or Coomassie blue, $\mathrm{CB}$ ) and associated autoradiographic patterns of proteins present in these tissues and separated by SDSPAGE (7.5\% acrylamide separating gel). The molecular weights were established from the migration of the following protein standards: myosin $(205 \mathrm{kDa})$, $\beta$-galactosidase (116 kDa), phosphorylase b $(97.4 \mathrm{kDa})$, bovine plasma albumin $(66 \mathrm{kDa})$, ovalbumin $(45 \mathrm{kDa})$, and carbonic anhydrase (29 kDa; Sigma). The open arrows indicate the location of the $122 \mathrm{kDa}$ protein. $B$, Densitometric scans of the above autoradiographs of the control and OCT-treated P-fractions. Such scans were used to quantitate the change in the phosphorylation of the $122 \mathrm{kDa}$ protein using the ratio of the area of the $122 \mathrm{kDa}$ protein and the area of a 95 $\mathrm{kDa}$ reference phosphoprotein $(R$, solid arrow). The $\mathrm{R}$ protein was present in each P-fraction, and its phosphorylation was unaffected by OCT treatment. 

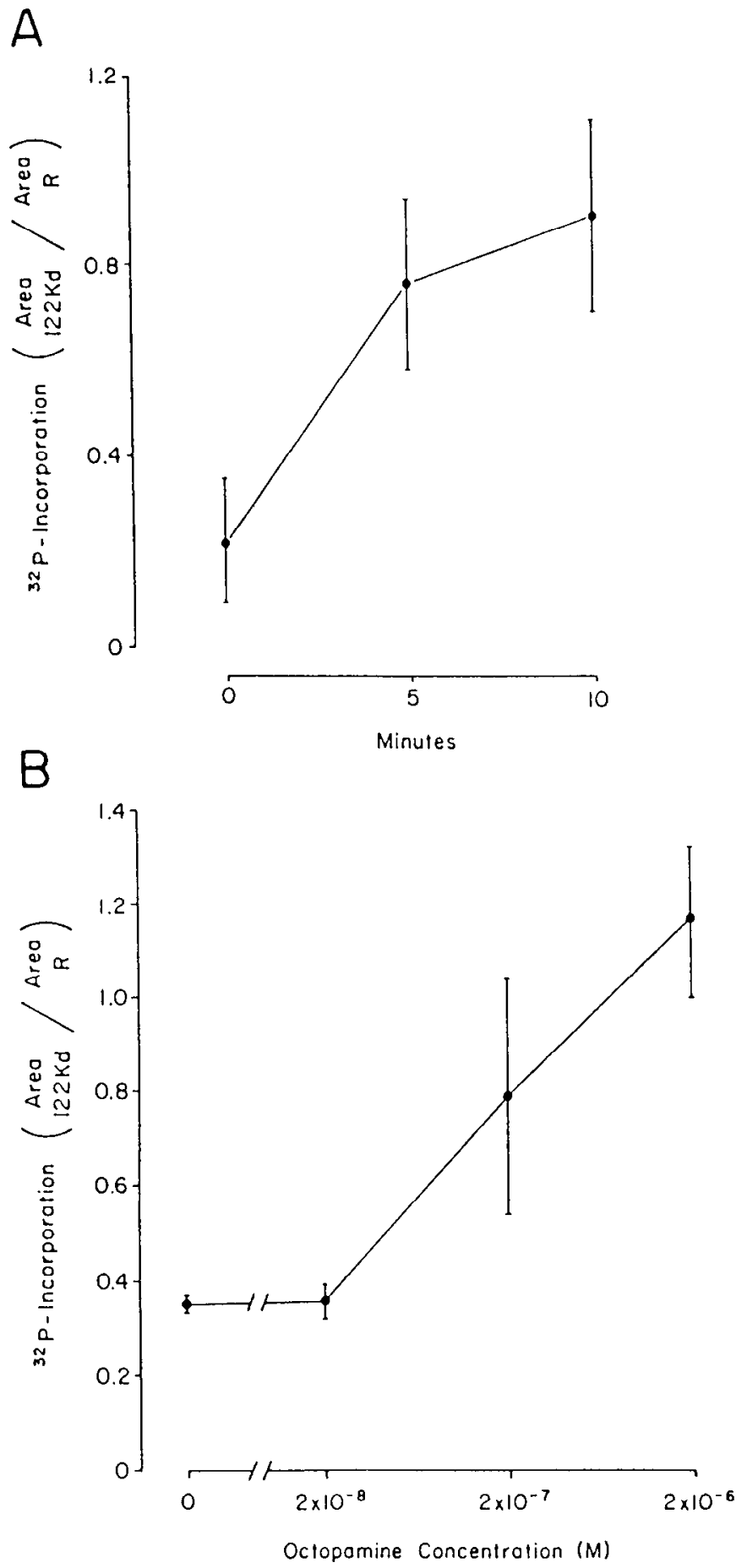

Figure 2. Characteristics of the OCT-stimulated phosphorylation of the $122 \mathrm{kDa}$ protein in intact ventral eye P-fractions. $A$, Time dependence using $2 \mu \mathrm{M}$ OCI $(n=3) . B$, Dose dependence with a $5 \mathrm{~min}$ exposure of the tissue to OCT $(n=6)$.

bodies and terminals of efferent fibers (Evans et al., 1983). The A-fraction is enriched in axons of both of these cells. Both ventral eye fractions contain glial cells. The lateral eye is composed of photoreceptor, eccentric, pigment, cone and glial cells, and axons of efferent fibers. The LON contains the axons originating and terminating in the lateral eye and the lateral rudimentary eye. These differences in cellular composition are reflected in the different SDS-gel staining patterns of the preparations and their patterns of basal protein phosphorylation (Fig. 1A). Comparing these patterns, 2 significant observations emerge. (1) Each preparation contains a major protein band that migrates with the $116 \mathrm{kDa}$ standard. This band has a calculated molecular weight of $122 \mathrm{kDa}$ (Weber and Osborn, 1969). (2) The patterns of basal phosphorylation of the A-fractions of the ventral eye and the LON are similar, both having a major phosphorylated band at $66 \mathrm{kDa}$.

OCT-stimulated phosphorylation of a $122 \mathrm{kDa}$ protein in the ventral eye $P$-fraction and the lateral eye

OCT stimulates an increase in the phosphorylation of a protein with an apparent molecular weight of $122 \mathrm{kDa}$ in intact P-fractions of the ventral eye (Fig. 1, $A, B$ ). The protein nature of the radioactively labeled $122 \mathrm{kDa}$ band was confirmed by its susceptibility to proteolytic digestion (see later section). Although a lightly ${ }^{32} \mathrm{P}$-labeled $122 \mathrm{kDa}$ phosphoprotein is also present in the A-fraction (Fig. 1A), OCT does not stimulate any detectable change in its phosphorylation.

OCT does not appear to reproducibly affect the phosphorylation of other proteins present in either the intact P- or A-fractions. However, the percentage acrylamide used in the SDS-PAGE to produce optimal separation of the $122-\mathrm{kDa}$ protein may have prevented the detection of affected phosphoproteins in the very high or low molecular weight ranges. Likewise, the time of autoradiographic exposure of the gels may not have been sufficiently long to allow detection of affected minor proteins.

OCT stimulates the phosphorylation of a $122 \mathrm{kDa}$ protein in slices of the lateral eye but not in segments of the LON (Fig. $1 A$ ). This suggests that an OCT-stimulated phosphoprotein, similar to that found in the ventral eyc P-fraction, is present in the lateral eye. The OCT-stimulated phosphorylation of this protein in intact cells of the lateral eye is less reproducible than in the ventral eye-occurring in only 3 out of 8 experiments. Thus, we used the ventral eye preparation to analyze the properties, mechanism of phosphorylation, and subcellular distribution of the $122 \mathrm{kDa}$ protein.

\section{Characteristics of the OCT-stimulated phosphorylation in intact P-fractions}

The OCT-stimulated phosphorylation of the $122 \mathrm{kDa}$ protein is rapid, reaching maximal levels within 5 min of exposure (Fig. $2 A$ ). Furthermore, incubation of the tissue with increasing concentrations of OCT $(0.02-2.0 \mu \mathrm{M})$ results in a dose-dependent increase in the incorporation of the labeled phosphate into the $122 \mathrm{kDa}$ protein (Fig. $2 B$ ).

To test whether the phosphorylation is a response to activation of a specific OCT receptor, we tested an OCT antagonist, an OCT analog, a mctabolic precursor, and other putative neurotransmitters present in Limulus for their ability to block or mimic the OCT effect (Table 1). Phentolamine, an OCT receptor blocker, blocks the OCT-stimulated phosphorylation (Table 1). Synephrine, an N-methylated form of OCT stimulates the phosphorylation of the $122 \mathrm{kDa}$ protein (Table 1); tyramine, the immediate metabolic precursor of OCT, has no significant effect. Treatment of intact P-fractions with other putative neurotransmitters present in the Limulus CNS and/or lateral eye (O'Conner et al., 1982; Chamberlain et al., 1986) produces a variety of results (Table 1). 5-HT and dopamine are ineffective. Norepinephrine, on the other hand, mimics the OCT effect (Table 1). 
The norepinephrine-stimulated phosphorylation is also blocked by phentolamine (data not shown).

Differential centrifugation of homogenates prepared from OCT-treated P-fractions in low-ionic-strength medium reveals that the $122 \mathrm{kDa}$ protein is both cytoplasmic and membrane associated (data not shown).

\section{Cyclic AMP-mediated phosphorylation of the $122 \mathrm{kDa}$ phosphoprotein}

In experiments using intact cells, 8-bromo cAMP, a phosphodiesterase-resistant and more lipophilic form of cAMP, and forskolin, a nonspecific adenylate cyclase stimulator, stimulate the phosphorylation of the $122 \mathrm{kDa}$ protein in P-fractions (Table 1) but not in A-fractions. No other ventral eye protein showed a reproducible increase in phosphorylation in response to these agents. In cell homogenates, 8-bromo cAMP stimulates a rapid (1-5 min) increase in the phosphorylation of the $122 \mathrm{kDa}$ protein in both the P- and A-fractions of the ventral eye, lateral eye, and LON (Fig. 3). 8-Bromo cAMP also stimulates the phosphorylation of 2 additional proteins with approximate molecular weights of 170 and $55 \mathrm{kDa}$ in homogenates of each of the tissues examined. In homogenates of the lateral eye and LON, up to 8 other 8-bromo cAMP-stimulated phosphoproteins are observed over a wide molecular-weight range and with variable degrees of phosphorylation (Fig. 3).

Interestingly, 8-bromo cGMP $(10 \mu \mathrm{M})$ also stimulates the phosphorylation of the $122 \mathrm{kDa}$ protein in intact P-fractions (data not shown). The relative potencies of the guanine and adenosine cyclic nucleotides have not yet been determined.

Limited proteolytic digestion of the $122 \mathrm{kDa}$ protein, which was phosphorylated in response to octopamine, 8-bromo cAMP, and forskolin, with $S$. aureus V8 protease produced labeled peptides with the same molecular weights (Fig. 4A). Similar results were obtained when chymotrypsin was used (Fig. 4B). Acid hydrolysis of the OCT-stimulated $122 \mathrm{kDa}$ protein revealed that only serines were phosphorylated (data not shown).

\section{Two-dimensional separation of $P$-fraction proteins}

The $122 \mathrm{kDa}$ silver-stained protein constitutes a significant portion $(3 \%)$ of the total silver-stained proteins in the P-fraction. In IEF-2D gel electrophoresis, this protein appeared as a streak with an isoelectric point between 6.2 and 6.4 (Fig. 5, $A, B$ ). Fluorographs of IEF-2D gels of OCT-treated intact P-fractions (Fig. 5A) and 8-bromo cAMP-trcated homogenatcs (Fig. 5B) indicate that the silver-stained streak is the affected ${ }^{32} \mathrm{P}$-labeled protein. The only other $122 \mathrm{kDa}$ protein is an acidic phosphoprotein, represented as a barely detectable silver-stained spot. The phosphorylation of this protein is unaffected by OCT or cAMP treatment (Fig. 5, $A, B$ ). IEF-2D separation of homogenates of ventral eye A-fractions treated with 8-bromo cAMP showed that the migration of the affected $122 \mathrm{kDa}$ phosphoprotein in this tissue was the same as that in the P-fraction (data not shown). Using NEPHGE (Fig. 5C), a 2-dimensional system that better separates proteins with neutral or basic isoelectric points (O'Farrell et al., 1977), the cAMP-stimulated $122 \mathrm{kDa}$ phosphoprotein and its associated silver stain run as a single spot (Fig. 5C).

\section{Discussion}

We have found that $\mathrm{OCT}$ and cAMP stimulate the phosphorylation of a $122 \mathrm{kDa}$ protein in both the ventral and lateral eyes of Limulus. Our evidence, together with the results of previous
Table 1. Relative effectiveness of an OCT antagonist, various neuroactive agents, a cAMP analog, and a nonspecific adenylate cyclase stimulator to increase the phosphorylation of the $122 \mathrm{kDa}$ protein in intact P-fractions of the Limulus ventral eye

\begin{tabular}{|c|c|c|c|}
\hline Agent & $N^{a}$ & $\begin{array}{l}\text { Phosphorylation } \\
\text { of the } 122 \mathrm{kDa} \\
\text { protein }^{b}\end{array}$ & $\begin{array}{l}\text { Percentage } \\
\text { of OCT } \\
\text { effect }\end{array}$ \\
\hline \multicolumn{4}{|l|}{ OCT antagonist } \\
\hline None & 5 & $0.49 \pm 0.13^{c}$ & - \\
\hline Phentolamine $(20 \mu \mathrm{M})^{d}$ & 5 & $0.52 \pm 0.20$ & 4 \\
\hline \multicolumn{4}{|l|}{ Phentolamine $(20 \mu \mathrm{M})^{d}$} \\
\hline +Octopamine & 5 & $0.57 \pm 0.21$ & 11 \\
\hline Octopamine & 5 & $1.23 \pm 0.39^{*}$ & 100 \\
\hline \multicolumn{4}{|l|}{ OCT precursor and analog } \\
\hline None & 3 & $0.15 \pm 0.05$ & - \\
\hline Tyramine & 3 & $0.25 \pm 0.10$ & 21 \\
\hline Synephrine & 3 & $0.47 \pm 0.11^{*}$ & 70 \\
\hline Octopamine & 3 & $0.60 \pm 0.11^{*}$ & 100 \\
\hline \multicolumn{4}{|c|}{ Other putative neurotransmitters in Limulus } \\
\hline None & 3 & $0.32 \pm 0.06$ & - \\
\hline $5-\mathrm{HT}$ & 3 & $0.24 \pm 0.02$ & 0 \\
\hline Octopamine & 3 & $0.76 \pm 0.17^{*}$ & 100 \\
\hline None & 4 & $0.27 \pm 0.08$ & - \\
\hline Dopamine & 3 & $0.23 \pm 0.05$ & 0 \\
\hline Norepinephine & 4 & $0.73 \pm 0.14^{*}$ & 63 \\
\hline Octopamine & 4 & $0.99 \pm 0.08^{*}$ & 100 \\
\hline \multicolumn{4}{|l|}{$\mathrm{c} \Lambda \mathrm{MP}$ and forskolin } \\
\hline None $e^{e}$ & 5 & $0.33 \pm 0.13$ & - \\
\hline 8-bromo cAMP $(10 \mu \mathrm{M})$ & 5 & $0.86 \pm 0.21^{*}$ & 96 \\
\hline Forskolin $(10 \mu \mathrm{M})$ & 5 & $1.39 \pm 0.38^{*}$ & 155 \\
\hline Octopamine & 4 & $0.86 \pm 0.07^{*}$ & 100 \\
\hline
\end{tabular}

Listed are a series of experiments in which P-fractions were exposed for 5 min to a $2 \mu \mathrm{M}$ concentration of each agent unless otherwise indicated. Results are expressed as an average percentage of the OCT-stimulated increase in P-fractions from the same animal.

Asterisks indicate a significantly different result from control $(p<0.05)$.

${ }^{a}$ Number of experiments.

${ }^{b}$ Ratio of the areas of the 122 and $95 \mathrm{kDa}$ phosphoproteins.

c Mean \pm 1 SEM.

${ }^{d}$ Phentolamine-treated tissues were exposed to phentolamine for $10 \mathrm{~min}$ prior to exposure to control saline or OCT plus phentolamine.

e Controls were treated with $0.02 \%$ ethanol, the vehicle for forskolin administration.

studies, suggests that the OCT-stimulated phosphorylation of this protein occurs via a cAMP-dependent mechanism: (1) OCT increases intracellular cAMP in ventral eye $\mathbf{P}$-fractions (Kaupp et al., 1982) and in the lateral eye (Battelle, unpublished observations). (2) Phentolamine blocks both the OCT-stimulated increase in cAMP in Limulus eyes and the OCT-stimulated phosphorylation of the $122 \mathrm{kDa}$ protein. (3) Limited proteolytic digestion of the $122 \mathrm{kDa}$ protein, whether phosphorylated in response to OCT, forskolin, or 8-bromo cAMP, yields the same phosphorylated peptide fragments. We interpret these latter results to mean that all 3 agents phosphorylate the same protein at the same sites.

Cyclic AMP may not be the only intracellular mechanism for the phosphorylation of the $122 \mathrm{kDa}$ protein, however. Treatment of the tissue with 8-bromo cGMP also stimulates the phosphorylation of the protein. The significance of this effect is presently unclear. The ability of OCT to increase the intracellular levels of cGMP in Limulus eyes has not been examined. 

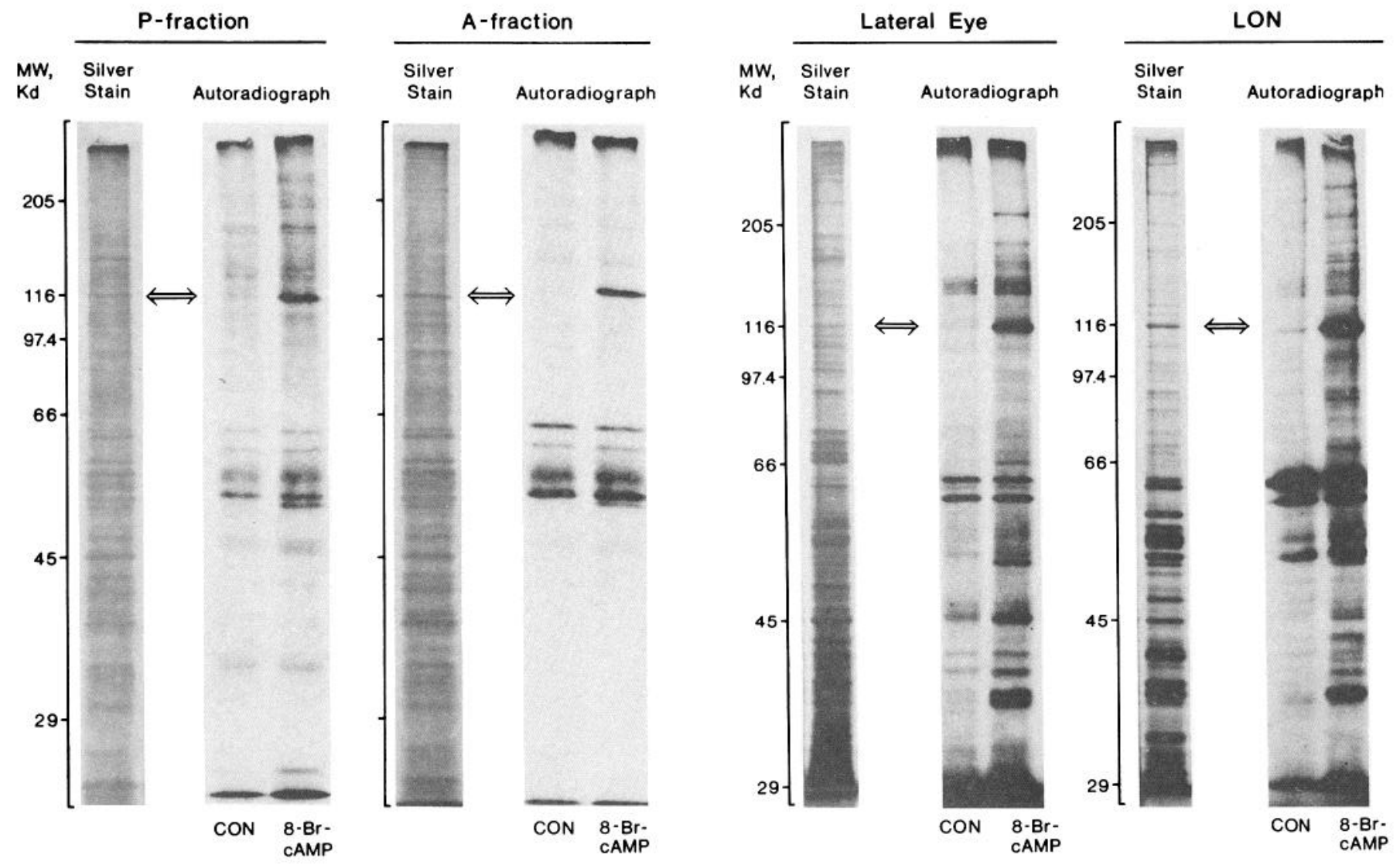

Figure 3. 8-bromo cAMP-stimulated phosphorylation of proteins in homogenates of P- and A-fractions of the ventral eye, lateral eyes, and lateral optic nerves $(L O N)$. Shown are the protein staining patterns and associated radioactivity visualized by autoradiography of tissue homogenates following separation by SDS-PAGE. Following addition of $30 \mu \mathrm{M}$ ATP containing $20 \mu \mathrm{Ci}$ of $\gamma$-32P-labeled ATP, the homogenates were incubated for $5 \mathrm{~min}$ in control phosphorylation medium $(C O N)$ or in medium containing $10 \mu \mathrm{M} 8$-bromo cAMP. These autoradiographs represent $1 \mu \mathrm{g}$ protein for both the P- and A-fractions and $10 \mu \mathrm{g}$ protein for both the lateral eye and LON. The open arrow indicates the migration of the $122 \mathrm{kDa}$ protein in each homogenate.

\section{Pharmacology of the receptor-mediated phosphorylation of the $122 \mathrm{kDa}$ protein}

Three of our observations are consistent with the idea that OCT exerts its influence on phosphorylation by activating a specific membrane receptor: (1) Phentolamine, an $\alpha$-adrenergic blocker and an OCT receptor blocker in a variety of invertebrate preparations, including Limulus (Atkinson et al., 1977; Evans, 1981), inhibits the OCT-stimulated increase in phosphorylation; (2) synephrine, the N-methylated analog of OCT, which activates the OCT receptor in a number of preparations (Harmar and Horn, 1977; Battelle and Kravitz, 1978), including the Limulus lateral eye (Kass and Barlow, 1984), stimulates the phosphorylation of the $122 \mathrm{kDa}$ phosphoprotein; and (3) tyramine, the immediate metabolic precursor of OCT, is ineffective.

Norepinephrine also stimulates the phosphorylation of the $122 \mathrm{kDa}$ phosphoprotein, and this stimulation is blocked by phentolamine. Since phentolamine is an $\alpha$-adrenergic receptor blocker, as well as an OCT receptor blocker, we cannot determine from these experiments whether norepinephrine and OCT activate the same or different receptors.

\section{Cellular distribution of the $122 \mathrm{kDa}$ subtrate protein and its phosphorylation}

The $122 \mathrm{kDa}$ protein is present in the lateral eyes, LON, and $\mathrm{P}$ - and A-fractions of the ventral eye. It is a substrate for cAMP- dependent phosphorylation in homogenates of each of these tissues. The inability of forskolin and 8-bromo cAMP to stimulate the phosphorylation of the $122 \mathrm{kDa}$ protein in intact A-fractions of the ventral eye and in the LON suggests that in these axon-enriched tissues the protein is not normally a substrate for the cAMP-dependent protein kinase. The $122 \mathrm{kDa}$ protein may be spatially separated from the kinase within the same cell, or the kinase and the $122 \mathrm{kDa}$ protein may be present in separate cells. Alternatively, the homogenization process may, in some manner, alter the physical conformation of the $122 \mathrm{kDa}$ protein in these tissues, transforming it to a form that can act as a substrate for the kinase.

The cellular composition of the ventral eye A-fraction is the same as the P-fraction, except that the P-fraction is enriched with photoreceptor cell bodies and efferent axon terminals. Since the photoreceptor cell bodies represent the major portion of the $\mathrm{P}$-fraction tissue, we believe that the $122 \mathrm{kDa}$ protein and the intracellular machinery for its increased phosphorylation by OCT or other stimulants are present in the photoreceptor cell bodies. Consistent with the hypothesis is the observation that the OCTcontaining efferent fibers project specifically to the ventral photoreceptor cell bodies (Evans et al., 1983). However, we cannot presently rule out the possibility that OCT acts presynaptically at the efferent terminal to cause the release of an unknown compound that then interacts with its own receptor on the pho- 

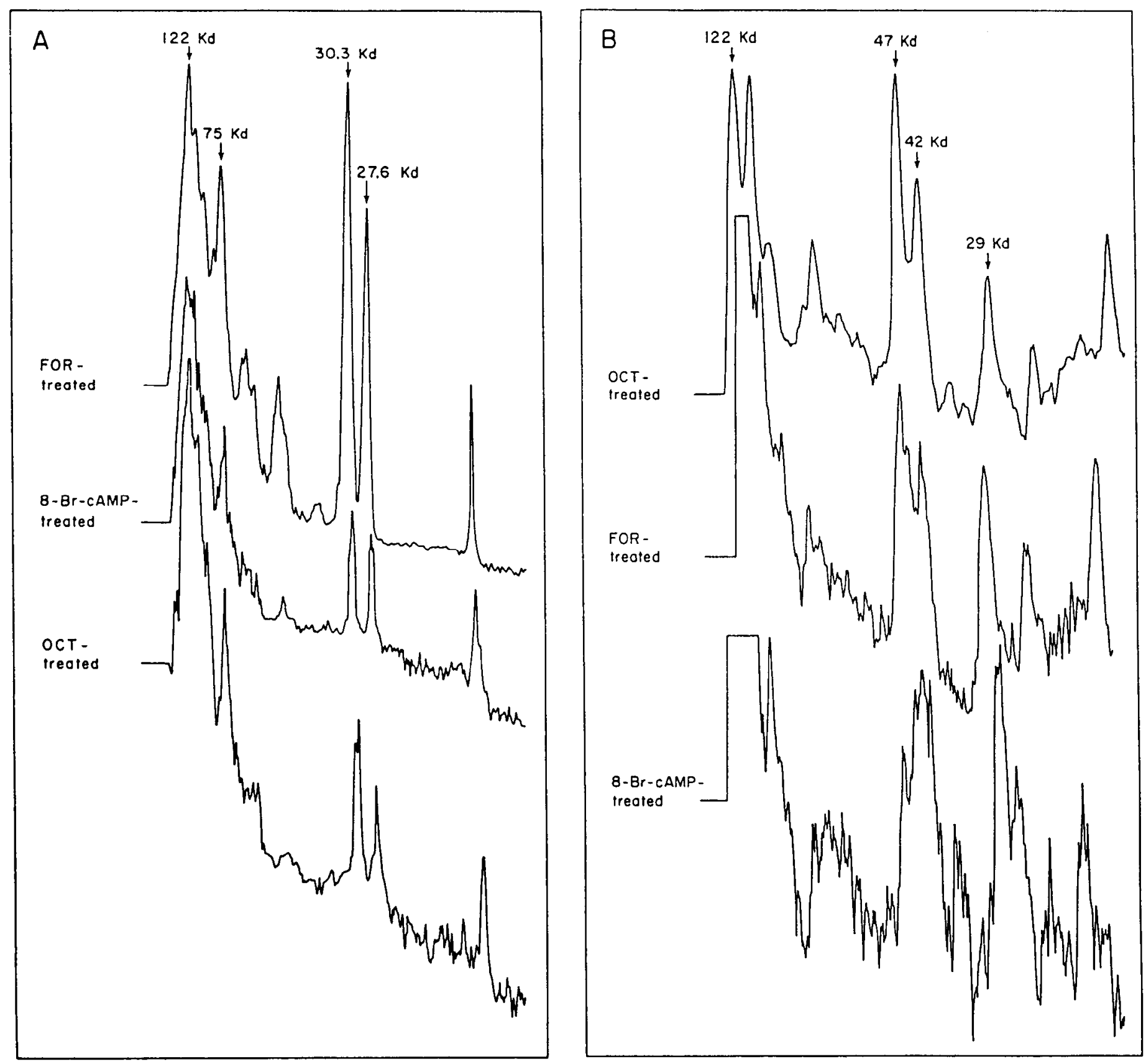

Figure 4. Densitometric scans of autoradiographs of ${ }^{32} \mathrm{P}$-labeled peptides produced by limited proteolytic digestion of the $122 \mathrm{kDa}$ protein. The phosphorylated protein was produced by a 5 min treatment of intact P-fractions with $2 \mu \mathrm{M}$ OCT, $10 \mu \mathrm{M}$ forskolin $(F O R)$, or $10 \mu \mathrm{M} 8$-bromo cAMP. Gel fragments from SDS-PAGE containing the labeled $122 \mathrm{kDa}$ protein were treated with $0.025 \mu \mathrm{g}$ of $S$. aureus V8 protease (A) or $2.5 \mu \mathrm{g}$ of TLCKtreated chymotrypsin $(B)$ using the method of Cleveland et al. (1977). The reduced resolution of the scan of the 8-bromo cAMP-stimulated 122 $\mathrm{kDa}$ protein treated with chymotrypsin shown in $B$ was due to a lower amount of radioactivity associated with the protein and, therefore, with the resulting peptides.

toreceptor cell to stimulate the phosphorylation of the $122 \mathrm{kDa}$ protein.

Phosphorylation of the $122 \mathrm{kDa}$ protein is routinely observed in homogenates of the lateral eye in response to 8-bromo cAMP, and OCT-stimulated phosphorylation of this protein has been observed (although not consistently) in slices of the lateral eye. OCT reproducibly increases intracellular cAMP in lateral eye slices (Battelle, unpublished observations), and OCT produccs a number of clear physiological effects both in the intact lateral eye in situ (Kass and Barlow, 1984) and in slices maintained in vitro (Pelletier et al., 1984). Our failure to obtain reproducible OCT-stimulated phosphorylation of the $122 \mathrm{kDa}$ protein in the slices may simply be a reflection of our experimental conditions, which were optimized for observing phosphorylation in the ventral eye, and may be less than optimal for the lateral eye preparation.

The lateral eye contains a number of different cell types, most of which receive input from OCT-containing efferent fibers (Fahrenbach, 1985). At this stage of our investigation it is not clear which of these cells contain the $122 \mathrm{kDa}$ phosphoprotein. 


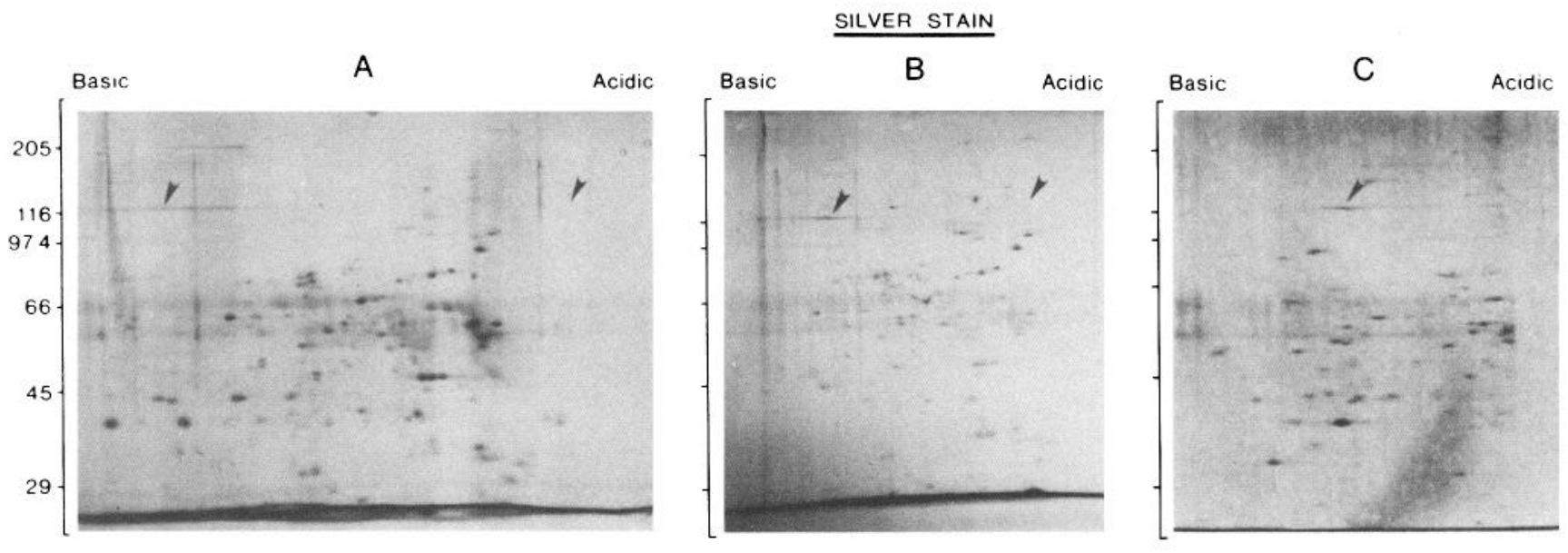

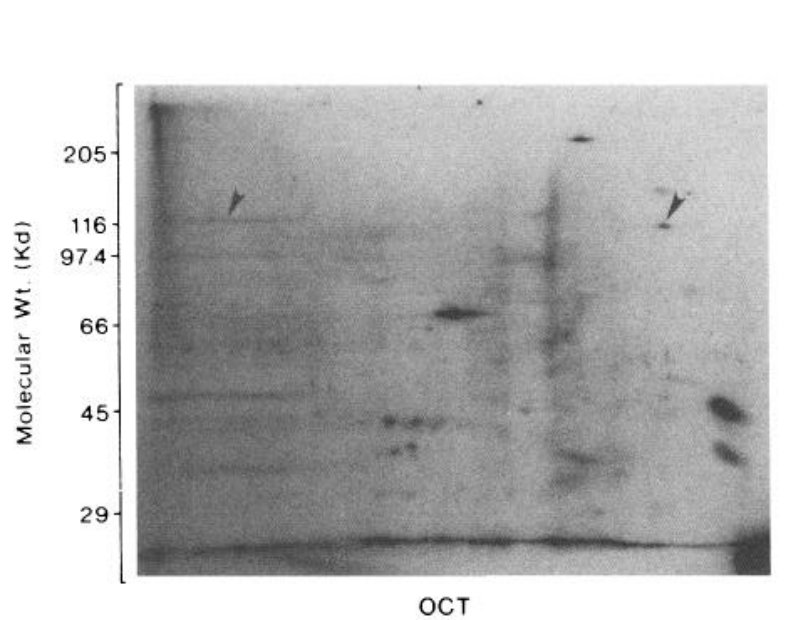

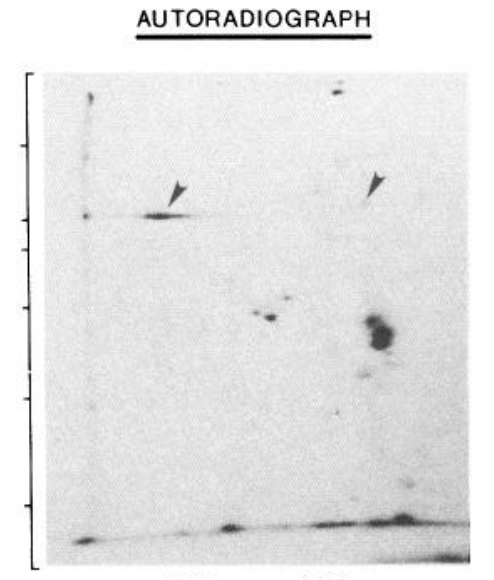

8-Bromo-cAMP

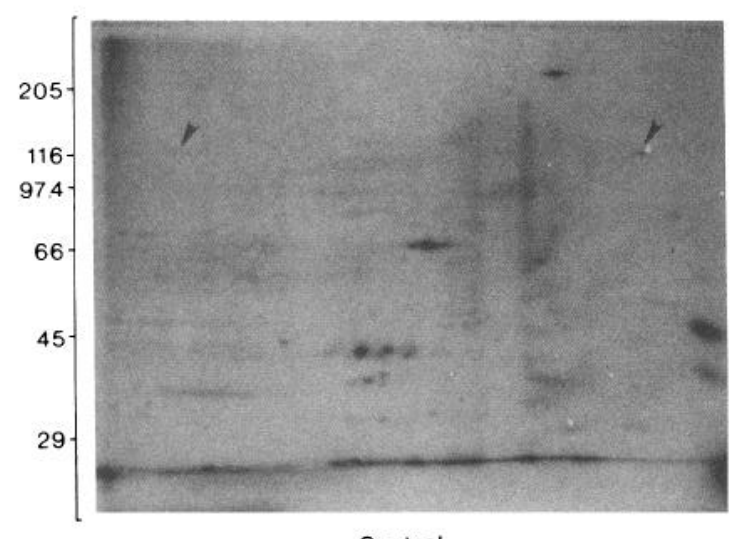

Control

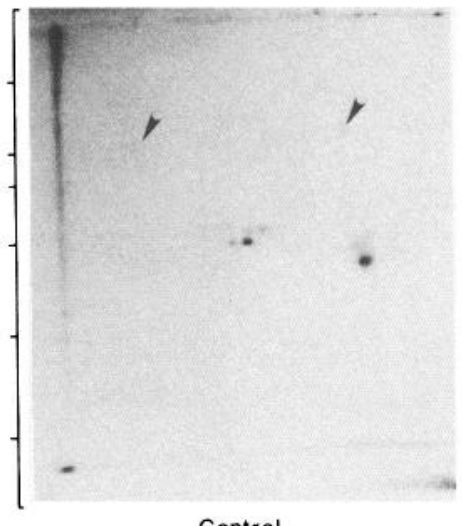

Control

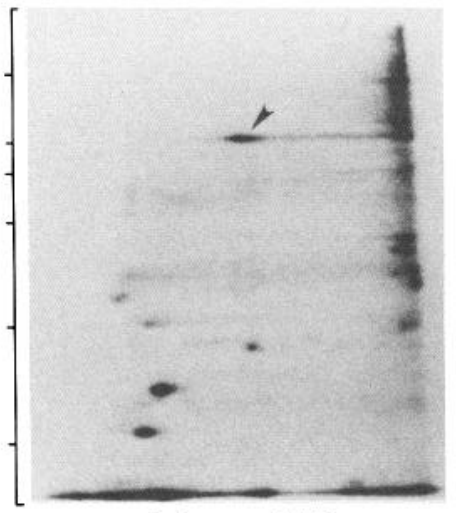

8-Bromo-cAMP

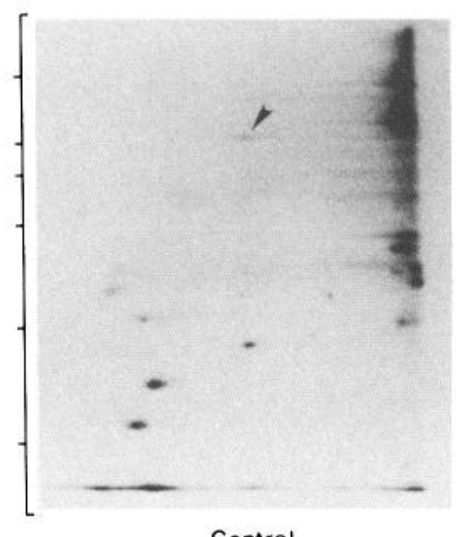

Control

Figure 5. Two-dimensional separation of the $122 \mathrm{kDa}$ protein from P-fraction tissue extracts using IEF $(A$ and $B)$ or nonequilibrium pH gradient electrophoresis (NEPHGE, $C$ ) followed by SDS-PAGE. $A$, Intact P-fractions treated for 5 min with saline or $2 \mu \mathrm{M}$ OCT. $B$ and $C$, P-fraction homogenate treated for $5 \mathrm{~min}$ with $10 \mu \mathrm{M} 8$-bromo cAMP. For IEF, the proteins were run into gels containing $1.5 \% \mathrm{pH} \mathrm{3-10} \mathrm{and} 0.5 \% \mathrm{pH} 5-7$ ampholytes (LKB) using $50 \mathrm{~V}$ for $30 \mathrm{~min}$ and then focused toward their isoelectric points using $400 \mathrm{~V}$ for $12 \mathrm{hr}$ and $800 \mathrm{~V}$ for $1 \mathrm{hr}$. For NEPHGE,

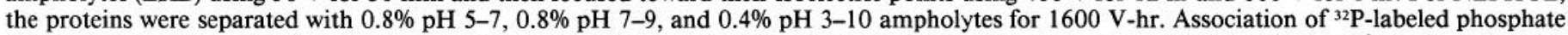
with cellular proteins was determined by autoradiography employing intensifying screens. The arrows toward the basic end of gels in $A-C$ point to the OCT- or 8 -bromo cAMP-stimulated $122 \mathrm{kDa}$ protein. The arrows toward the acidic end of the gels in $A$ and $B$ point to a $122 \mathrm{kDa}$ phosphoprotein that is unaffected by OCT or 8-bromo cAMP.

\section{Characteristics of the $122 \mathrm{kDa}$ protein}

We confirmed using 2-dimensional gel electrophoresis that the OCT- and cAMP-stimulated phosphoprotein is a major cellular protein in both the ventral eye P-fraction, which is enriched in photoreceptor cell bodies, and the A-fraction, which is enriched in photoreceptor cell axons. In ventral eye P-fractions the protein may be associated with membranes, but it is not an integral membrane protein. Phosphorylation also does not detectably change the distribution of the protein between the membrane and cytoplasmic compartments. 
Relationship of OCT-stimulated phosphorylation of the 122 $k D a$ protein and the physiological effects of OCT on Limulus eyes

As summarized in the introduction, the circadian, nocturnal firing of efferent neurons that innervate Limulus eyes increases the sensitivity of the eyes to light and increases the eyes' ability to dark-adapt. OCT has been identified as the neurotransmitter responsible for initiating cellular events that lead to the functional changes. These are generated in whole or in part by alterations in electrophysiological properties of the photoreceptor cells. The function of the $122 \mathrm{kDa}$ protein is not yet known. Since it is phosphorylated in response to OCT only in those preparations that contain photoreceptor cell bodies, our working hypothesis is that it is involved in processes that occur in photoreceptor cell bodies. Examples of 2 possible processes are the following: (1) Efferent input and OCT increase voltage-dependent gain in lateral eye photoreceptor cells apparently by decreasing the effectiveness of voltage-sensitive $\mathrm{K}^{+}$channels (Barlow et al., 1985; Renninger, personal communication). (2) OCT and $\mathrm{C} \Lambda \mathrm{MP}$ are thought to increase the rate of dark adaptation in Limulus ventral photoreceptors by enhancing the removal of intracellular $\mathrm{Ca}^{2+}$, possibly by stimulating a $\mathrm{Ca}^{2+}$ pump or a Na$\mathrm{Ca}$ exchange mechanism (O'Day and Lisman, 1985). Each of these processes has been correlated with cAMP-stimulated phosphorylation of specific proteins in a number of different systems (Scheid et al., 1979; Alkon et al., 1983; Lindemann et al., 1983; Neyses et al., 1985; Shuster et al., 1985).

\section{Other phosphorylated proteins}

In this study we have focused on the ability of OCT and cAMP to stimulate an increase in the phosphorylation of the $122 \mathrm{kDa}$ protein in P-fractions of the ventral eye and the lateral eye. The conditions were optimized for analysis of this protein. Very high or low molecular weight proteins, or proteins not as heavily or as reliably phosphorylated in response to OCT, forskolin, or 8-bromo cAMP, may have been overlooked. Given the multiplicity of effects of OCT and cAMP, particularly in the lateral eye (Kass et al., 1983; Kass and Barlow, 1984), we think it unlikely that the $122 \mathrm{kDa}$ protein is the only protein phosphorylated in response to these stimuli. Other proteins phosphorylated in response to cAMP in homogenates of ventral eye P-fractions and lateral eyes (Fig. 4) are candidates for future consideration as protcin intermediatcs for the physiological effects of cAMP and possibly OCT on Limulus vision. At the same time, it must be kept in mind that proteins phosphorylated in homogenates may not be substrates for protein kinases in intact tissue.

\section{Summary}

In summary, we have shown that when OCT, 8-bromo cAMP, or forskolin is applied to intact cell bodies from P-fractions of Limulus ventral eyes or to slices of lateral eyes, it stimulates the phosphorylation of a $122 \mathrm{kDa}$ protein. This protein, or a very similar protein, is also phosphorylated in homogenates of the LON and A-fractions of the ventral eye in response to 8 -bromo cAMP. These results suggest that the $122 \mathrm{kDa}$ substrate protein may be widely distributed in the Limulus peripheral visual system but that its phosphorylation in intact tissues is restricted to tissues containing photoreceptor cell bodies. The function of the $122 \mathrm{kDa}$ protein is not yet known. Based on the comparative pharmacological properties of the phosphorylation of the $122 \mathrm{kDa}$ protein and the documented physiological effects of OCT in Limulus lateral and ventral eyes, we suggest that the $122 \mathrm{kDa}$ protein may be an intermediate in one or more of the effects of OCT on Limulus vision.

\section{References}

Alkon, D. L., J. Acosta-Urguidi, J. Olds, G. Kuzma, and J. T. Neary (1983) Protein kinase injection reduces voltage-dependent $\mathrm{K}^{+}$currents. Science 219: 303-306.

Atkinson, M. M., W. S. Herman, and J. R. Sheppard (1977) An octopamine sensitive adenylate cyclase in the central nervous system of Limulus polyphemus. Comp. Biochem. Physiol. 58C: 107-1 10.

Barlow, R. B., Jr., S. Bolanski, Jr., and M. L. Brachman (1977) Efferent optic nerve fibers mediate circadian rhythm in the Limulus eye. Science 197: 86-88.

Barlow, R. B., Jr., E. Kaplan, G. H. Renninger, and T. Saito (1985) Efferent control of circadian rhythms in the Limulus lateral eye. Neurosci. Res. 2(Suppl.): S65-S78.

Battelle, B-A. (1980) Neurotransmitter candidates in the visual system of Limulus polyphemus: Synthesis and distribution of octopamine. Vis. Res. 20: 911-922.

Battelle, B-A. (1984) Efferent innervation to Limulus eyes. Trends Neurosci. 7: 277-282.

Battelle, B-A., and J. A. Evans (1984) Octopamine release from centrifugal fibers of the Limulus peripheral visual system. J. Neurochem. 42: 71-79.

Battelle, B-A., and E. A. Kravitz (1978) Targets of octopamine action in the lobster: Cyclic nucleotide changes and physiological effects in hemolymph, heart, and exoskeletal muscle. J. Pharmacol. Exp. Ther. 205: 438-448.

Rattelle, B-A., J. A. Evans, and S. C. Chamberlain (1982) Efferent fibers to Limulus eyes synthesize and release octopamine. Science 216: 1250-1252.

Benovic, J. L., L. J. Pike, R. A. Cerione, C. Staniszewski, T. Yoshimasa, J. Codina, M. G. Caron, and R. J. Lefkowitz (1985) Phosphorylation of the mammalian beta-adrenergic receptor by cyclic AMP-dependent protein kinase. J. Biol. Chem. 260: 7094-7101.

Chamberlain, S. C., and R. B. Barlow Jr. (1979) Light and efferent activity control rhabdom turnover in Limulus photoreceptors. Science 206: 361-363.

Chamberlain, S. C., J. Pepper, B-A. Battelle, G. A. Wyse, and T. J. Lewandowski (1986) Immunoreactivity in Limulus. II. Studies of serotonin-like immunoreactivity, endogenous serotonin, and serotonin synthesis in the brain and lateral eye. J. Comp. Neurology 251: 363-375.

Cleveland, D. W., S. G. Fischer, M. W. Kirschner, and U. K. Laemmli (1977) Peptide mapping by limited proteolysis in sodium dodecyl sulfate and analysis by gel electrophoresis. J. Biol. Chem. 252: 11021106.

Cooper, J. A., B. M. Sefton, and T. Hunter (1983) Detection and quantification of phosphotyrosine in proteins. Methods Enzymol. 99: $387-405$.

Dougan, D. F. H., and D. N. Wade (1978) Octopamine receptors and their structural specificity. Clin. Exp. Pharmacol. Physiol. 27: 219.

Edwards, S. C. (1984) Neurohormonal involvement of octopamine in cell volume regulation in Limulus polyphemus. Ph.D. thesis, University of Maryland, College Park, MD.

Edwards, S. C., and S. K. Pierce (1984) Neuromodulation of cell volume regulation by octopamine in Limulus during hypoosmotic stress. Am. Zool. 24: 3a.

Evans, J. A., S. C. Chamberlain, and B-A. Battelle (1983) Autoradiographic localization of newly-synthesized octopamine to retinal efferents in the Limulus visual system. J. Comp. Neurol. 219: 369383.

Evans, P. D. (1981) Multiple receptor types for octopaminc in the locust. J. Physiol. (Lond.) 318: 99-122.

Fahrenbach, W. H. (1985) Anatomical circuitry of lateral inhibition in the eye of the horseshoe crab, Limulus polyphemus. Proc. R. Soc. London [Biol.] 225: 219-249.

Goy, M. F., T. L. Schwarz, and E. A. Kravitz (1984) Serotonin-induced protein phosphorylation in a lobster neuromuscular preparation. $\mathbf{J}$. Neurosci. 4: 611-616.

Harmar, A. J., and A. S. Horn (1977) Octopamine-sensitive adenylate 
cyclase in cockroach brain: Effects of agonists, antagonists, and guanylyl nucleotides. Mol. Pharmacol. 13: 512-520.

Hildebrand, J. G., D. L. Barker, E. Herbert, and E. A. Kravitz (1971) Screening for neurotransmitters: A rapid radiochemical procedure. J. Neurobiol. 2: 231-246.

Kass, L., and R. B. Barlow Jr. (1984) Effcrent ncurotransmission of circadian rhythms in Limulus lateral eye. I. Octopamine-induced increases in retinal sensitivity. J. Neurosci. 4: 908-917.

Kass, L., J. L. Pellitier, G. H. Renninger, and R. B. Barlow, Jr. (1983) cAMP: A possible intracellular transmitter of circadian rhythms in Limulus photoreceptors. Biol. Bull. 165: 540.

Kaupp, U. B., C. C. Malbon, B.-A. Battelle, and J. E. Brown (1982) Octopamine stimulated rise in cAMP in Limulus ventral photoreceptors. Vis. Res. 22: 1503-1506.

Laemmli, U. K. (1970) Cleavage of structural proteins during assembly of the head of the bacteriophage T4. Nature 277:680-685.

Levitan, I. B., and S. H. Barondes (1974) Octopamine- and serotoninstimulated phosphorylation of a specific protein in the abdominal ganglion of Aplysia californica. Proc. Natl. Acad. Sci. USA 71: 11451148 .

Lindemann, J. P., L. R. Jones, D. R. Hathaway, B. G. Henry, and A. M. Watanabe (1983) Beta-adrenergic stimulation of phospholamban phosphorylation and $\mathrm{Ca}^{2+}$-ATPase activity in guinea pig ventricles. J. Biol. Chem. 258: 464-471.

Nestler, E. J., and P. Greengard (1984) Protein Phosphorylation in the Nervous System. Wiley, New York.

Neyses, L., L. Reinlib, and E. Carafoli (1985) Phosphorylation of the $\mathrm{Ca}^{2+}$ pumping ATPase of heart and sarcolemma and erythrocyte plasma membrane by the cAMP-dependent protein kinase. J. Biol. Chem. 260: 10283-10287.

Novak-Hofer, I., J. R. I emos, M. Villermain, and I. B. Levitan (1985) Calcium- and cyclic nucleotide-dependent protein kinases and their substrates in the Aplysia nervous system. J. Neurosci. 5: 151-159.

O'Conner, E. F., W. H. Watson, III, and G. A. Wyse (1982) Identification and localization of catecholamines in the nervous system of Limulus polyphemus. J. Neurobiol. 13: 49-60.
O'Day, P. M., and J. E. Lisman (1985) Octopamine enhances darkadaptation in Limulus ventral photoreceptors. J. Neurosci. 5: 14901496.

O'Farrell, P. H. (1975) High resolution two-dimensional electrophoresis of proteins. J. Biol. Chem. 250:4007-4021.

O'Farrcll, P. Z., H. M. Goodman, and P. H. O'Farrell (1977) High resolution two dimensional electrophoresis of basic as well as acidic proteins. Cell 12: 1133-1142.

Pelletier, J. L., L. Kass, G. H. Renninger, and R. B. Barlow, Jr. (1984) cAMP and octopamine partially mimic a circadian clock on Limulus photoreceptors. Invest. Ophthal. Vis. Sci. (Suppl). 25: 288.

Peterson, G. L. (1977) A simplification of the protein assay method of Lowry et al., which is more applicable. Anal. Biochem. 83: 346356.

Scheid, C. R., T. W. Honeyman, and F. S. Fay (1979) Mechanism of beta-adrenergic relaxation of smooth muscle. Nature 277: 32-36.

Seamon, K. B., W. Padgett, and J. W. Daly (1981) Forskolin: Unique diterpene activator of adenylate cyclase in membranes and in intact cells. Proc. Natl. Acad. Sci. USA 78: 3363-3367.

Shuster, M. J., J. S. Camardo, S. A. Siegelbaum, and E. R. Kandel (1985) Cyclic AMP-dependent protein kinase closes the serotoninsensitive $\mathrm{K}^{+}$channels of Aplysia sensory neurones in cell-free membrane patches. Nature 313: 392-395.

Steel, R. G. D., and J. H. Torrie (1980) Principles and Procedures of Statistics, a Biometrical Approach, 2nd ed. McGraw-Hill, New York.

Stieve, H., and E. Andre (1984) Octopamine modulates the sensitivity of Limulus ventral photoreceptor. Z. Naturforsch., Teil C 39: 981985.

Warren, M. K., and S. K. Pierce (1982) Two cell volume regulatory systems in the Limulus myocardium: An interaction of ions and quaternary ammonium compounds. Biol. Bull. 163: 504-516.

Weber, K., and M. Osborn (1969) The reliability of molecular weight determinations by dodecyl-sulfate-polyacrylamide electrophoresis. J. Biol. Chem. 241: 4406-4412. 